\title{
Intravenous oxygen administration in a rat model of hypoxia
}

\author{
E Damiani ${ }^{1,2^{*}}$, A Donati $^{1}$, M Singer $^{2}$ \\ From ESICM LIVES 2015 \\ Berlin, Germany. 3-7 October 2015
}

\section{Introduction}

Hypoxemia reduces tissue oxygen delivery, thus compromising cell metabolism and organ function. Supplemental oxygen at high concentrations may prove ineffective and issues relating to hyperoxia, barotrauma, mechanical ventilation and extracorporeal oxygenation are well documented $[1,2]$. A century ago, Tunnicliffe et al reported rapid and safe relief of cyanosis in patients by administration of intravenous oxygen gas [3]. This re-discovered route warrants re-exploration.

\section{Objectives}

To test the safety and efficacy of intravenous administration of oxygen either as a pure gas or dissolved in Ringer's Lactate (RL) solution saturated to $100 \%$.

\section{Methods}

Under isoflurane anesthesia, male Wistar rats (about $300 \mathrm{~g}$ bw) underwent arterial and central venous cannulation, tracheotomy, bladder cannulation and placement of tissue $\mathrm{PO}_{2}$ probes (Oxford Optronix, Oxford, UK) in leg muscle and liver. Hypoxia was induced by breathing a hypoxic gas mix $\left(\mathrm{FiO}_{2} 0.1\right)$. At 60 minutes, a continuous iv infusion of pure $\mathrm{O}_{2}$ gas $(2 \mathrm{~mL} / \mathrm{kg} / \mathrm{h})$ or oxygenated $\mathrm{RL}(10 \mathrm{~mL} / \mathrm{kg} / \mathrm{h})$ was begun. An equal volume of normal RL was given to controls. Echocardiography, arterial blood gas analysis, mean arterial pressure (MAP), urine output, muscle and liver $\mathrm{tPO}_{2}$ were measured at baseline and at hourly intervals for 4 hours.

\section{Results}

Infusion of pure $\mathrm{O}_{2}$ gas caused early death due to pulmonary embolism so this technique was abandoned. Administration of oxygenated $\mathrm{RL}\left(\mathrm{PO}_{2}\right.$ of solution at

'Università Politecnica delle Marche, Biomedical Sciences and Public Health, Ancona, Italy

Full list of author information is available at the end of the article end-experiment $=87.5 \pm 1.7 \mathrm{kPa}$ ) was however safe but did not produce any significant increase in $\mathrm{PaO}_{2}$ or $\mathrm{SaO}_{2}$, in comparison to controls. However, $\mathrm{O}_{2}$ delivery, MAP (Figure 1) and liver $\mathrm{PO}_{2}$ (Figure 2) (but not muscle $\mathrm{PO}_{2}$ ) rose progressively with oxygenated $\mathrm{RL}$ with urine output increasing to supranormal values (Figure 3).

\section{Conclusions}

In this rat model of hypoxia, the intravenous infusion of oxygenated RL was safe. While it did not produce any increase in arterial or muscle oxygenation, it did appear to impact on the splanchnic circulation, increasing liver $\mathrm{PO}_{2}$ and urine output.

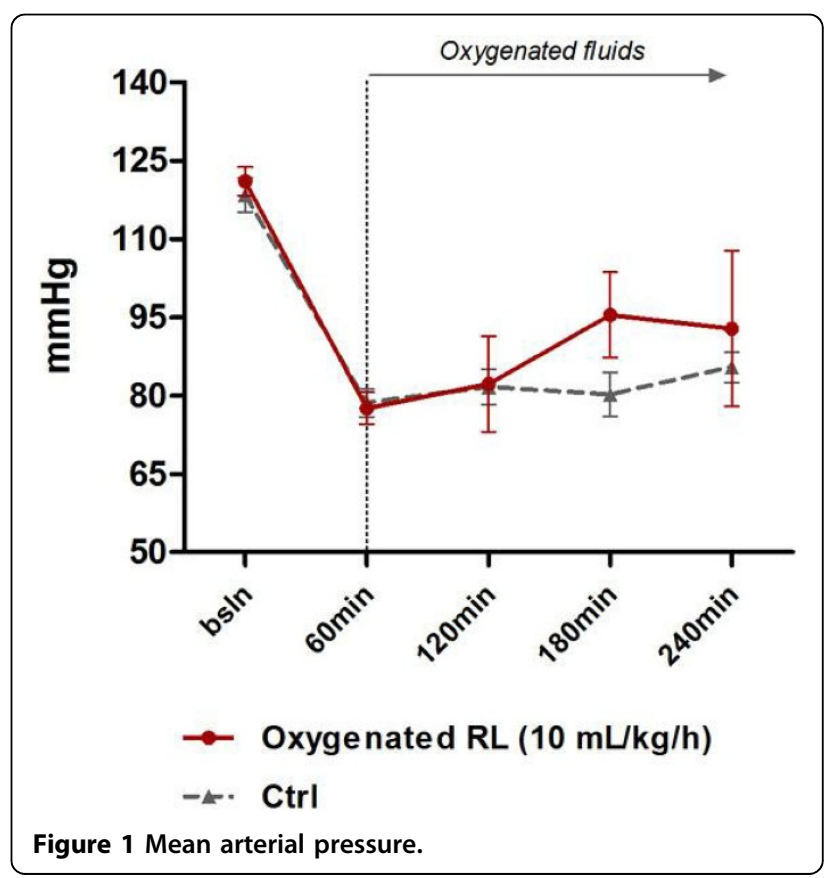

(c) 2015 Damiani et al.; This is an Open Access article distributed under the terms of the Creative Commons Attribution License (http:// creativecommons.org/licenses/by/4.0), which permits unrestricted use, distribution, and reproduction in any medium, provided the original work is properly cited. 

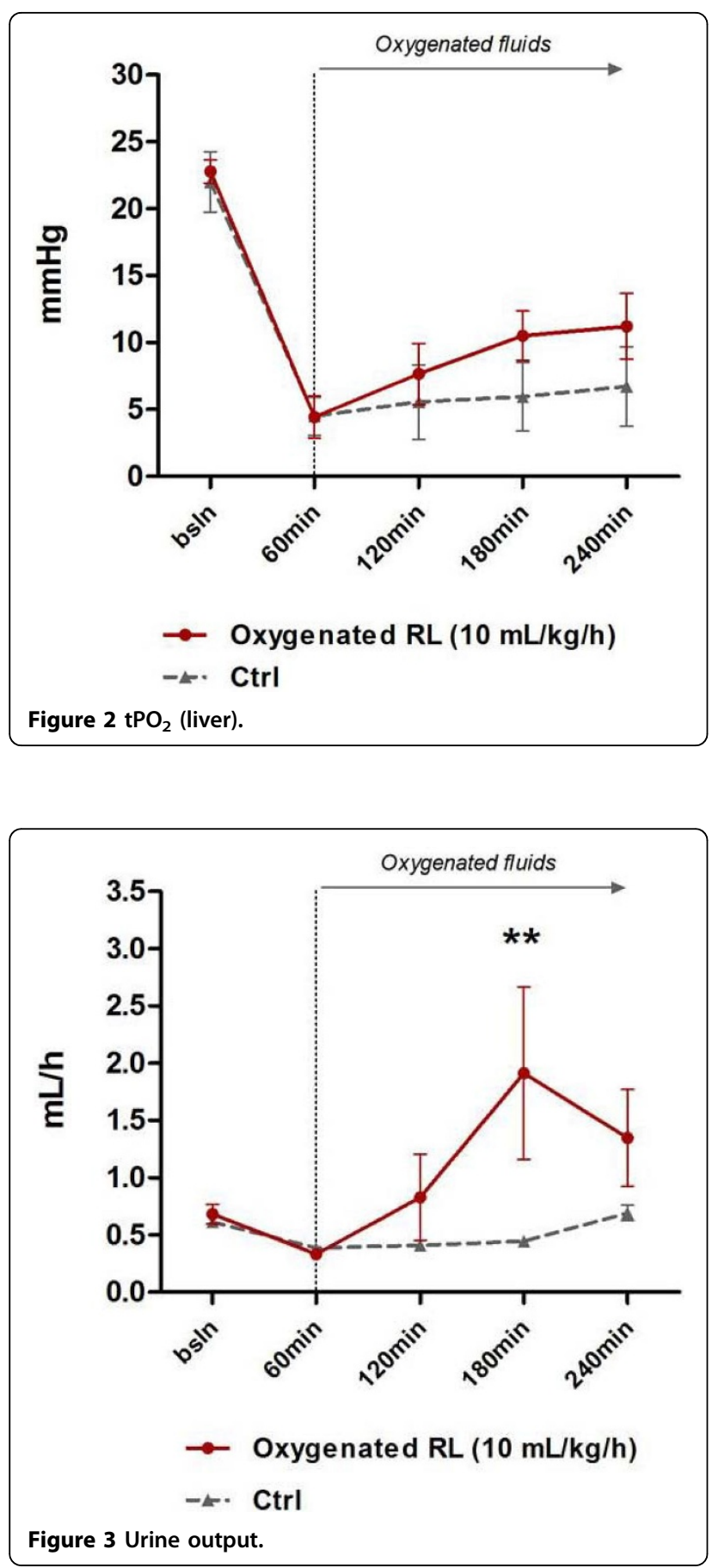

\section{Authors' details}

'Università Politecnica delle Marche, Biomedical Sciences and Public Health, Ancona, Italy. ${ }^{2}$ University College London, Bloomsbury Institute of Intensive Care Medicine, London, United Kingdom.

Published: 1 October 2015

\section{References}

1. Budinger GRS, Mutlu GMI: Balancing the Risks and Benefits of Oxygen Therapy in Critically III Adults. Chest 2013, 143(41):1151-1162.
2. Tramm R, llic D, Davies AR, Pellegrino VA, Romero L, Hodgson C: Extracorporeal membrane oxygenation for critically ill adults. Cochrane Database Syst Rev 2015, 1:CD010381.

3. Tunnicliffe FW, Stebbing GF: The intravenous injection of oxygen gas as a therapeutic measure. Lancet 1916, 188(4851):321-323.

doi:10.1186/2197-425X-3-S1-A575

Cite this article as: Damiani et al:: Intravenous oxygen administration in a rat model of hypoxia. Intensive Care Medicine Experimental 2015

3(Suppl 1):A575.

\section{Submit your manuscript to a SpringerOpen ${ }^{\odot}$ journal and benefit from:}

- Convenient online submission

- Rigorous peer review

- Immediate publication on acceptance

- Open access: articles freely available online

- High visibility within the field

- Retaining the copyright to your article

Submit your next manuscript at $>$ springeropen.com 